\title{
Influence of the nature of cell wall carbohydrates on the anatomico-functional development of the digestive tract in the rabbit
}

\author{
M. CANDAU, G. DELPON et J. FIORAMON'TI(*) \\ Laboratoive de Zootechnie, Ecole nationale supérieure agronomique, \\ 3 Io76 Toulouse Cedex (France) \\ (*) Laboratoive de Physiologie, I.N.R.A., Ecole national vétérinaive, \\ 3 I076 Toulouse Cedex (France)
}

A total of 192 young rabbits of both sexes were slaughtered at the age of $3-5-7-9-1$ I-1 $3-15$ and 17 weeks. The dams and the new-born rabbits were fed ad libitum with one of the two experimental diets. The diets differed essentially by the nature of the cell wall carbohydrates coming either from dried lucerne (40 p. Ioo of the diet) or from dried beetroot pulps (50 p. I00 of the diet).

No significant difference in the weight gain could be pointed out between both diets. On the contrary, the dry matter intake was larger ( + I 7 p. Ioo) with the lucerne diet. As compared with the latter, the pulp diet induced a hypertrophy and a very marked distention of the stomach from 9 weeks onwards; it also resulted in an important increase in the volune and weight of the caecum at the same age. On the contrary the weight of both the liver and the caecal appendix was reduced. The effects on the sniall intestine were not significant. The increase in the caecal contents after pulp feeding was accompanied by an increase in the concentrations of total volatile fatty acids. The proportion of butyric acid was higher than that of propionic acid.

\section{Gastro-intestinal motility as affected by the dietary cell wall constituents (carbohydrates) in the rabbit}

\author{
J. FIORAMONTI, L. BUENO et M. CANDAU $\left({ }^{*}\right)$ \\ Laboratoive de Physiologie, École nationale vétérinaire, \\ 3 Io76 Toulouse I.N.R.A. Cedex (France) \\ (*) Laboratoire de Zootechnie, École nationale supérieuve agronomique, \\ 3 I076 Toulouse Cedex (France)
}

The effects of a diet based on beetroot pulp (high hemicellulose/cellulose ratio) on the motility of the digestive tract and on the feeding pattern were compared with a dried lucerne diet (low $\mathrm{H} / \mathrm{C}$ ratio). With the pulp diet, the mean duration of a meal was threefold increased and the ingestion rate redured. The physical form of the pulp diet induced continuous antral hypermotility with reduction of the postprandial response of both stomach and caecum. The circadian variations of the caecocolonic motility were enhanced; it is suggested that metabolic factors were involved. 